\title{
An audit of the impact of Covid-19 pandemic on the emotional wellbeing of children and parents with problematic severe asthma
}

\begin{abstract}
COVID-19 pandemic and the associated redeployment of healthcare infrastructure had significant impact on normal services. Amongst a cohort of with severe asthma children and young persons, attending a regional service, this questionnaire explored the impact of the pandemic and associated lockdown on emotional well-being.

Our findings suggest that there were significant anxieties associated with the ability to access primary and secondary care services, medication during the pandemic - lockdown, as well as the psychological impact of social distancing and missing school work for this cohort. There was a common perception that this had adversely impacted their asthma control, although this was not clinically correlated.

Our results indicate the need for health care providers to be aware of the psychological impact on emotional wellbeing of the pandemic and offer appropriate help and counselling as needed. A correlation with deteriorating asthma control may need to be explored.
\end{abstract}

\section{Keywords}

Paediatric asthma; COVID-19, pandemic; emotional impact

\section{Introduction}

The clinical features of acute SARS-COV-2 infection in children are generally mild; accounting for $<2 \%$ of cases that have required hospitalization ${ }^{1}$. Furthermore, children with asthma have not been severely affected, with a reduction in admissions due to wheeze attacks having been observed during the pandemic period ${ }^{2}$. These epidemiological characteristics were not clear early in the course of the pandemic. Indeed, children with asthma were perceived to be at a higher risk of suffering from
Nadia Audi MBBS ${ }^{1 *}$, James Cook MBBS ${ }^{*}$, Becky Tomlin BSN ${ }^{1}$, Sarah Latham BSN ${ }^{1}$, Sulagna Chakrabarti MBBS2, Prasad Nagakumar[Res $]^{3}$, Atul Gupta MD[Res $]^{1}$

*These authors contributed equally to this work

${ }^{1}$ Department of Paediatric Respiratory Medicine, King's College Hospital, London

2Department of Child and Adolescent Psychiatry, South London and Maudsley NHS Foundation Trust, London

${ }^{3}$ Department of Paediatric Respiratory Medicine ,Women's and Children's Hospital NHS Foundation Trust, Birmingham

Corresponding Author

Email: atul.gupta@kcl.ac.uk

Cite as: Audi, N., Cook, J., Tomlin, B., Latham, S., Chakrabarti, S., Nagakumar, P., Gupta, A. (2021) Emotional impact of COVID-19 pandemic on children and parents with problematic severe asthma. Sushruta J Health Policy \& Opin Vol 14; Issue 2: 1-20 ePub 4.5.21 DOI https://doi.org/10.38192/14.2.3

Article Information Submitted 1.5.21 Published 4.5.21

ISSN 2732-5164 (Online) ISSN 2732-5156 (Print)

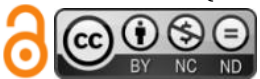


severe disease; a prospect that would reasonably be associated with high levels of anxiety in both children and parents.

Anxiety and stress, are associated with poor asthma control and can trigger wheeze attacks ${ }^{3}$. Moreover, parental stress can exacerbate a child's asthma Method

Children and young persons (CYP) diagnosed with severe asthma ${ }^{4}$, currently attending a tertiary level multidisciplinary difficult asthma clinic serving South London and South East England were identified.

Two questionnaires were developed to assess themes related to the COVID-19 pandemic which were considered important influences on emotional wellbeing and potentially on asthma control. One questionnaire was designed to be answered by parents and the other to be answered by CYP. Answers to each question were recorded on a categorical scale; never/sometimes/ often/always.

Printed copies of the questionnaires were sent by recorded delivery to the address of each patient on $5^{\text {th }}$ of June 2020. The questionnaires were completed anonymously and returned by post in pre-paid envelopes to the investigators. Questionnaires returned by $2^{\text {th }}$ of June 2020 were included in the analysis.

These questionnaires were registered with the local audit department as a service evaluation project.

\section{Results}

Questionnaires were sent by post to the households of the 58 CYP identified. 20 questionnaires completed by parents, and 14 questionnaires completed by CYP were returned. The median age of CYP was 11 years (range 4 to 18), 39 of 58 were males. A summary of the responses to each question are presented in table 1 and table 2 (appendix)

\section{Parental Questionnaire}

The majority of parents $17 / 20$ (85\%) were worried about their child having an asthma attack during the pandemic, with a particular contributory factor being concerns around access to normal healthcare services. Indeed, 16/20 (80\%) were concerned about accessing primary care services, 15/20 (75\%) were concerned about accessing hospital services and symptoms ${ }^{3}$. We hypothesized that the effect of social distancing measures and uncertainties around the SARS-COV-19 infection during the peak of the pandemic would result in detrimental effects on the emotional wellbeing of children with problematic severe asthma, impacting symptom control.

14/20 (70\%) were concerned about accessing regular prescriptions.

Parents reported that the emotional wellbeing of their child was impacting on asthma symptoms. The main contributory influences affecting asthma control were the impact of social distancing 14/20 (70\%), worry about school work 12/20 (60\%), and their child's anxiety around COVID-19 12/20 (60\%).

Parents' perception of the emotional welling being of their children was explored in further detail. 14/20 (70\%) reported observing feelings of sadness and irritability in their child, and 16/20 (80\%) observed increased levels of anxiety and lack of concentration. Changes in physical behaviors reflective of emotional changes were also reported; low energy 18/20 (90\%), restlessness $17 / 20$ (85\%) and difficulty in sleeping $12 / 20$ (60\%).

\section{Children's Questionnaire}

The majority of CYP 9/14 (64\%) were worried about an asthma attack during the pandemic. Accessing healthcare during an attack was of concern with $11 / 14(78 \%)$ worried about the prospect of a hospital visit. In contrast to their parents only 4/14 (28\%) were concerned about accessing regular prescriptions.

In common with their parents, CYP reported that their emotional wellbeing had influenced asthma symptoms. Factors reported to be impacting symptoms included impact of social distancing $7 / 14$ (50\%), and concerns regarding school work $7 / 14$ (50\%). A minority 4/14 (29\%) felt that concerns regarding COVID-19 had influenced their asthma symptoms.

The emotional wellbeing of the CYP was explored in further detail. In common with their parents the majority of CYP reported feelings of irritability $11 / 14$ (78\%), anxiety 9/14 (64\%), and difficulty with concentration $10 / 14(71 \%)$. Changes in physical behavior reflective of emotional changes were also 
reported, 9/14 (64\%) felt restless, and 7/14 (50\%) reported difficulty with sleeping.

\section{Discussion}

\section{Main findings}

The emotional impact of the COVID-19 pandemic on CYP with severe asthma appears significant. Our questionnaires have highlighted that anxiety around the challenges of accessing appropriate healthcare services, impact of social distancing measures and worry about school work impacted on emotional wellbeing. In turn these influences appeared to manifest as physical symptoms including reported worsening asthma control.

\section{Interpretation}

The role of stress and anxiety on asthma control is well described ${ }^{5}$. The emotional impact of COVID-19 on children is beginning to emerge and themes identified using this questionnaire have been reflected in other reports. As access to support networks at school and within the wider community of family and friends have been disrupted, stressors have accumulated and become amplified. Uncertainty about the future including worries about health, cancellation of exams, applications to college and financial security have all been reported as contributing to the experience of anxiety.

The charity, Young Minds, identified $83 \%$ of CYP as having experienced a worsening of their mental health ${ }^{6}$. Furthermore, specific concerns regarding accessing healthcare became apparent early on in the course of the pandemic with a sharp decline in paediatric emergency department attendances recorded, and concerns raised regarding delayed presentation of severe illness ${ }^{7}$.

\section{Limitations}

We acknowledge important limitations to this study. The sample size was small with a low response rate and the patients identified were all from the same tertiary regional clinic. It is possible the results may have differed in different parts of the UK. In addition there was no measurement of adherence or asthma control test score.

\section{Conclusion}

There has been a significant emotional impact of the COVID-19 pandemic on CYP with severe asthma, which is associated with a perception of worsening asthma control. An improved understanding of these factors amongst professionals involved in caring for these CYP may help with recognition of how the pandemic may be influencing asthma symptoms. Further research of a larger population, taking in to consideration correlation with asthma control, adherence to therapy, the additional impact of socioeconomic factors and demographics would be important.

\section{References}

1. Annemarie D, Ewen $\mathrm{H}$, Christopher $\mathrm{G}$ et al. Features of 20133 UK patients in hospital with covid-19 using the ISARIC WHO Clinical Characterization Protocol: prospective observational cohort study. BMJ 2020; 369 doi: https://doi.org/10.1136 /bmj.m1985

2. Elissa A, Stanley S. Managing Asthma during Coronavirus Disease-2019: An Example for Other Chronic Conditions in Children and Adolescents. $2020 \mathrm{Apr}$

21. doi: $10.1016 /$ j.jpeds.2020.04.049

3. Caroline H, Courtney D, Leonard B et al. Daily global stress is associated with nocturnal asthma awakenings in school-age children. April 20, 2016. DOI:10.1016/j.jaci.2016.01.054

4. Management of severe asthma: a European Respiratory Society/American Thoracic Society guideline. European Respiratory

Journal 2020 55: 1900588; DOI: 10.1183/13 993003.00588-2019

https://erj.ersjournals.com/content/55/1/1 900588

5. Ryan L, Glenda M. Psychological Factors in Asthma. 2008 Mar 15. doi: 10.1186/17101492-4-1-12

6. Coronavirus: Impact on young people with mental health needs. COVID-19 March 2020 survey youngminds.org.uk

7. Richard L, Jacob A, Simon L et al. Delayed access to care and late presentations in children during the COVID-19 pandemic: a snapshot survey of 4075 paediatricians in the UK and Ireland. 2020 Jun 25.doi: 10.1136/archdischild-2020-319848 
Conflicts of interest: There are no conflicts of interest

\section{Contribution}

Data collection and interpretation: NA, BT, AG, PN

Original draft preparation: NA, JC

Review and editing: AG, BT, SC, SL, PN
All authors reviewed and approved the final version of the manuscript

Funding Source: This research did not receive any specific grant from funding agencies in the public, commercial, or not-for-profit sectors.

\section{Appendix}

\section{Appendix 1:}

\section{COVID-19 SURVEY FOR CHILDREN AND ADOLESCENTS ATTENDING SPECIALIST ASTHMA SERVICE}

We are getting in touch with you because you attend our service at Kings College hospital and we wanted to know how you have been during the COVID -19 pandemic.

Please tick the most appropriate answer (ask your parent if you need help)

Asthma Symptoms - during the COVID-19 outbreak:

\begin{tabular}{|l|l|l|l|l|}
\hline 1. I have been worried about: & Never & Sometimes & Often & Always \\
\hline a) my asthma & & & & \\
\hline $\begin{array}{l}\text { b) my asthma symptoms } \\
\text { (cough/ wheeze/ shortness of } \\
\text { breath/ tight chest) }\end{array}$ & & & & \\
\hline $\begin{array}{l}\text { 2. Because of my asthma, I am } \\
\text { worried about: }\end{array}$ & & & & \\
\hline $\begin{array}{l}\text { a) being able to see a doctor if } \\
\text { needed }\end{array}$ & & & & \\
\hline $\begin{array}{l}\text { b) being able to speak to my } \\
\text { asthma team or specialist } \\
\text { service }\end{array}$ & & & & \\
\hline $\begin{array}{l}\text { c) getting my asthma } \\
\text { medication prescriptions }\end{array}$ & & & & \\
\hline
\end{tabular}




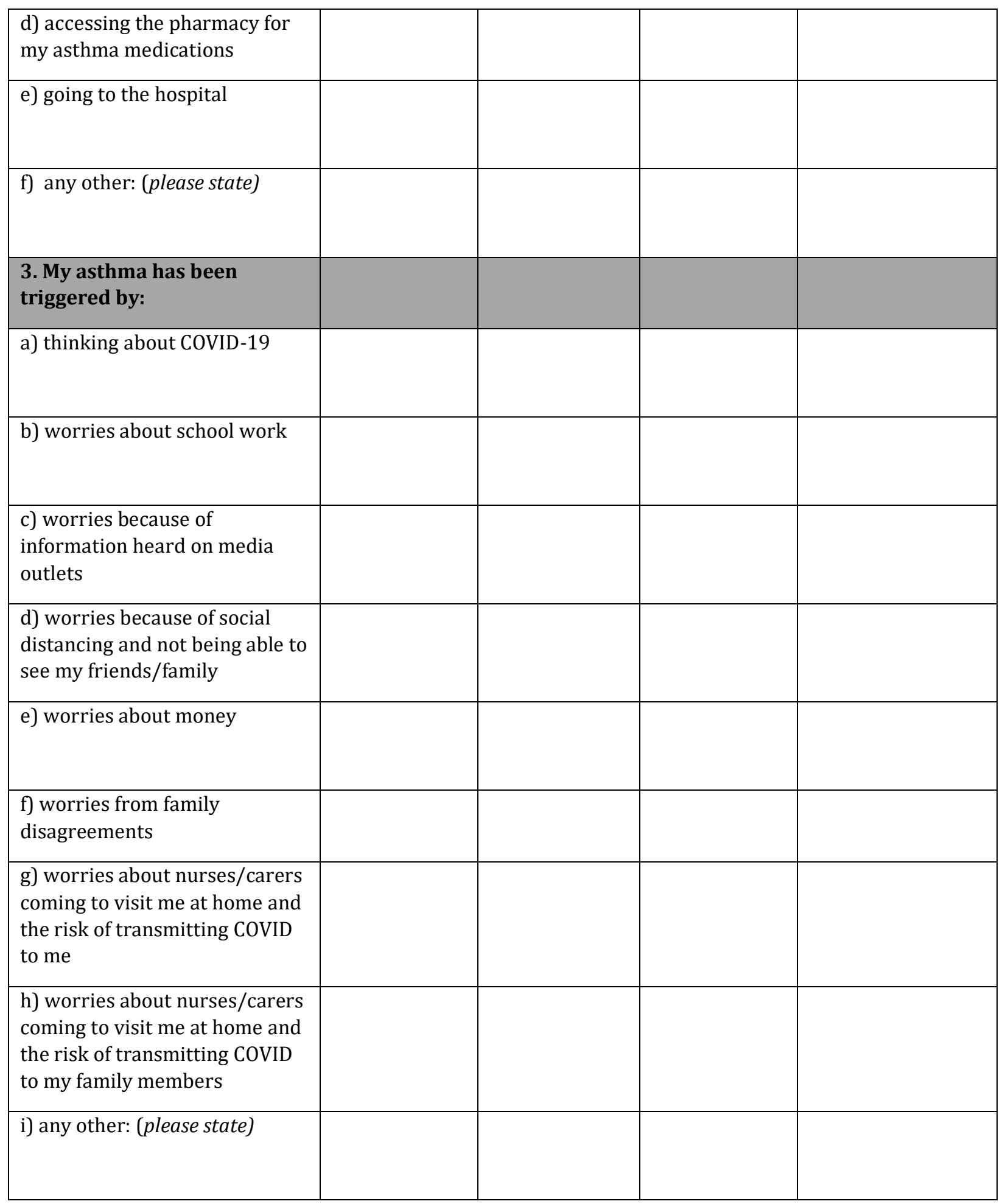

\section{Mood and Behaviour - during the COVID-19 outbreak:}




\begin{tabular}{|c|c|c|c|c|}
\hline $\begin{array}{l}\text { 4. Which of these feelings or } \\
\text { moods have you experienced } \\
\text { during this period }\end{array}$ & Never & Sometimes & Often & Always \\
\hline a) happiness & & & & \\
\hline b) irritability/moody & & & & \\
\hline c) angry & & & & \\
\hline d) sad/tearful & & & & \\
\hline e) depressed & & & & \\
\hline f) anxious/worried & & & & \\
\hline g) panic attacks & & & & \\
\hline h) thoughts of self-harm & & & & \\
\hline $\begin{array}{l}\text { 5. Which of these behaviours } \\
\text { have you displayed during } \\
\text { this period }\end{array}$ & & & & \\
\hline a) restless/fidgety & & & & \\
\hline b) lack of concentration & & & & \\
\hline c) tired with low energy levels & & & & \\
\hline d) relaxed & & & & \\
\hline $\begin{array}{l}\text { e) participation in your } \\
\text { hobbies/activities }\end{array}$ & & & & \\
\hline
\end{tabular}




\begin{tabular}{|l|l|l|l|l|}
\hline $\begin{array}{l}\text { f) I am sleeping too little/worse } \\
\text { than before }\end{array}$ & & & & \\
\hline g) I am sleeping too much & & & & \\
\hline h) I have lost my appetite & & & & \\
\hline i) I am eating too much & & & & \\
\hline
\end{tabular}

\section{Support:}

If you would like to have support with my mood, anxiety and/or worries about my asthma care / school work and/or my family please contact the specialist nurses 
COVID-19 SURVEY FOR PARENTS OF CHILDREN AND ADOLESCENTS ATTENDING SPECIALIST ASTHMA SERVICE

We are getting in touch with you because you attend our service at Kings College hospital and we wanted to know how you and your child have been during the COVID -19 pandemic.

Please tick the most appropriate answer

Asthma Symptoms - during the COVID-19 outbreak:

\begin{tabular}{|l|l|l|l|l|}
\hline $\begin{array}{l}\text { 1. I have been worried about } \\
\text { my child's: }\end{array}$ & Never & Sometimes & Often & Always \\
\hline a) asthma & & & & \\
\hline $\begin{array}{l}\text { b) asthma symptoms (cough/ } \\
\text { wheeze/ shortness of breath/ } \\
\text { tight chest) }\end{array}$ & & & & \\
\hline $\begin{array}{l}\text { 2. In relation to my child's } \\
\text { asthma, I am worried about: }\end{array}$ & & & & \\
\hline $\begin{array}{l}\text { a) accessing the GP if needed } \\
\text { b) accessing the specialist } \\
\text { asthma service }\end{array}$ & & & & \\
\hline $\begin{array}{l}\text { c) access to his/her asthma } \\
\text { medication prescriptions }\end{array}$ & & & & \\
\hline d) accessibility to the pharmacy & & & & \\
\hline $\begin{array}{l}\text { f) accessibility to the hospital } \\
\text { ener: (please state) }\end{array}$ & & & & \\
\hline
\end{tabular}




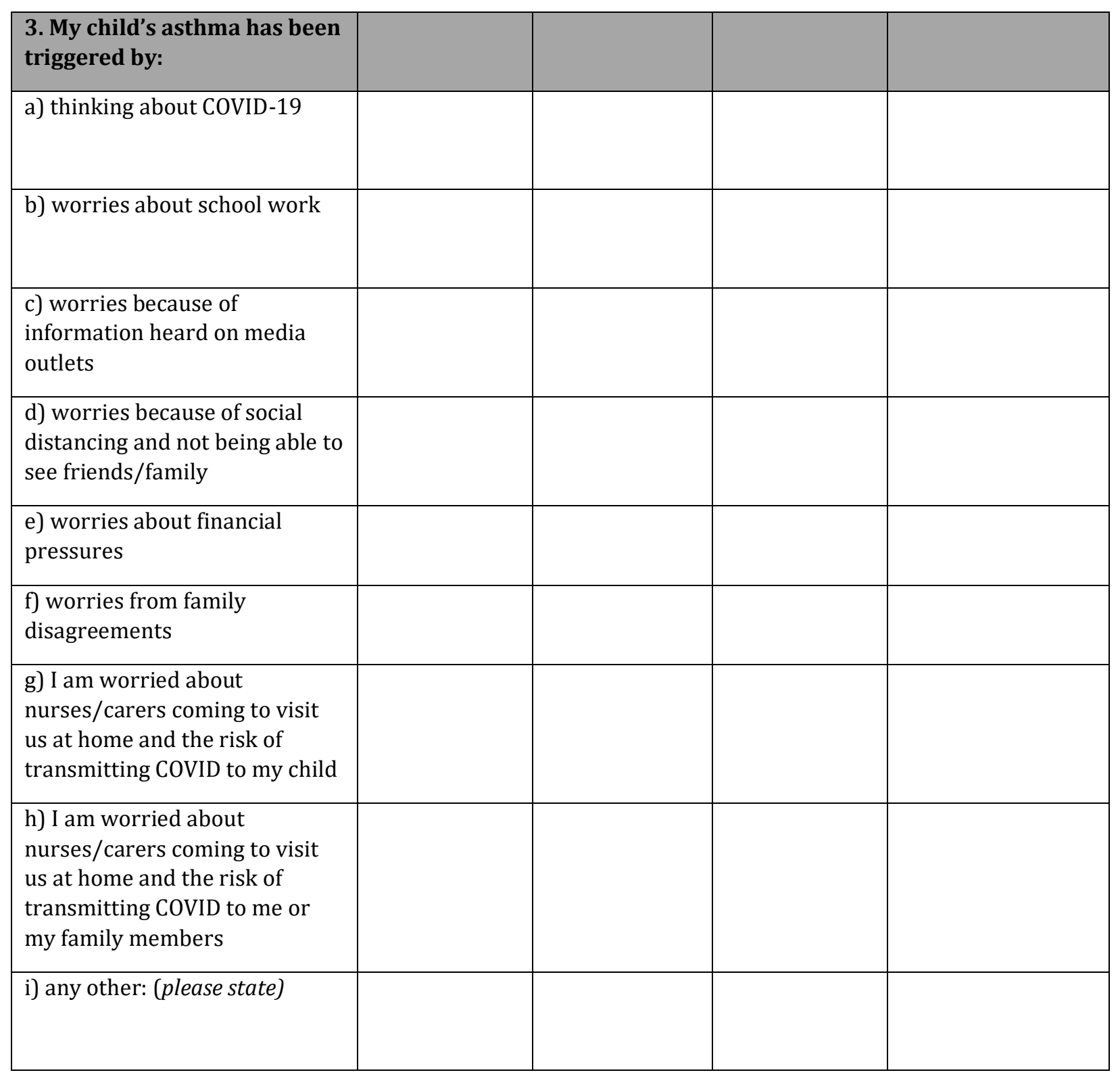

\section{Mood and Behaviour - during the COVID-19 outbreak:}

\begin{tabular}{|l|l|l|l|l|}
\hline $\begin{array}{l}\text { 4. Which of these feelings or } \\
\text { moods has your child } \\
\text { experienced during this } \\
\text { period }\end{array}$ & Never & Sometimes & Often & Always \\
\hline a) happiness & & & & \\
\hline b) irritability/moody & & & & \\
\hline
\end{tabular}




\begin{tabular}{|l|l|l|l|l|}
\hline & & & & \\
\hline c) angry & & & & \\
\hline d) sad/tearful & & & & \\
\hline e) depressed & & & & \\
\hline f) anxious/worried & & & & \\
\hline g) panic attacks & & & & \\
\hline h) thoughts of self-harm & & & & \\
\hline $\begin{array}{l}\text { 5. Which of these behaviours } \\
\text { has your child displayed } \\
\text { during this period }\end{array}$ & & & & \\
\hline a) restless/fidgety & & & & \\
\hline b) lack of concentration & & & & \\
\hline $\begin{array}{l}\text { e) participation in their } \\
\text { hobbies/activities }\end{array}$ & & & & \\
\hline $\begin{array}{l}\text { f) sleeping too little/worse than } \\
\text { before }\end{array}$ & & & & \\
\hline g) sleeping too much & & & & \\
\hline d) relaxed with low energy levels & & & & \\
\hline
\end{tabular}




\begin{tabular}{|l|l|l|l|l|}
\hline i) overeating & & & & \\
& & & & \\
\hline
\end{tabular}

\section{Support:}

If you would like to have support with my mood, anxiety and/or worries about my asthma care / school work and/or my family please contact the specialist nurses 
Table 1:

COVID-19 SURVEY FOR PARENTS OF CHILDREN AND ADOLESCENTS ATTENDING SPECIALIST ASTHMA SERVICE

Asthma Symptoms - during the COVID-19 outbreak:

\begin{tabular}{|c|c|c|c|c|c|}
\hline $\begin{array}{l}\text { 1. I have been worried } \\
\text { about my child's: }\end{array}$ & Never & Sometimes & Often & Always & Total \\
\hline a) asthma & III & 111111 & IIIII & IIIIII & 20 \\
\hline $\begin{array}{l}\text { b) asthma symptoms } \\
\text { (cough/ wheeze/ } \\
\text { shortness of breath/ tight } \\
\text { chest) }\end{array}$ & IIII & 1111111111 & IIII & IIII & 21 \\
\hline $\begin{array}{l}\text { 2. In relation to my } \\
\text { child's asthma, I am } \\
\text { worried about: }\end{array}$ & & & & & \\
\hline $\begin{array}{l}\text { a) accessing the GP if } \\
\text { needed }\end{array}$ & 1111 & IIIIIIIII & 111 & 1111 & 20 \\
\hline $\begin{array}{l}\text { b) accessing the specialist } \\
\text { asthma service }\end{array}$ & IIIIIIIIIII & 1111111 & 111 & 1 & 20 \\
\hline $\begin{array}{l}\text { c) access to his/her } \\
\text { asthma medication } \\
\text { prescriptions }\end{array}$ & 1111111 & 111111111 & III & 111 & 20 \\
\hline $\begin{array}{l}\text { d) accessibility to the } \\
\text { pharmacy }\end{array}$ & IIIIII & 11111111 & III & III & 20 \\
\hline $\begin{array}{l}\text { e) accessibility to the } \\
\text { hospital }\end{array}$ & $11111 \mathrm{I}$ & IIIIIIII & IIII & III & 20 \\
\hline $\begin{array}{l}\text { f) any other: (please } \\
\text { state) }\end{array}$ & & & & & \\
\hline $\begin{array}{l}\text { 3. My child's asthma has } \\
\text { been triggered by: }\end{array}$ & & & & & \\
\hline $\begin{array}{l}\text { a) thinking about COVID- } \\
19\end{array}$ & IIIIIIII & 1111111 & II & 1 & 18 \\
\hline
\end{tabular}




\begin{tabular}{|c|c|c|c|c|c|}
\hline $\begin{array}{l}\text { b) worries about school } \\
\text { work }\end{array}$ & 1111111 & Ill11111 & Ill & 1 & 19 \\
\hline $\begin{array}{l}\text { c) worries because of } \\
\text { information heard on } \\
\text { media outlets }\end{array}$ & 11111111 & 111111 & 1111 & 1 & 19 \\
\hline $\begin{array}{l}\text { d) worries because of } \\
\text { social distancing and not } \\
\text { being able to see } \\
\text { friends/family }\end{array}$ & 11111 & IIIIIIIII & Il & lll & 19 \\
\hline $\begin{array}{l}\text { e) worries about financial } \\
\text { pressures }\end{array}$ & 1111111111111111 & 1111 & & & 19 \\
\hline $\begin{array}{l}\text { f) worries from family } \\
\text { disagreements }\end{array}$ & 111111111111111 & 1111 & & & 18 \\
\hline $\begin{array}{l}\text { g) I am worried about } \\
\text { nurses/carers coming to } \\
\text { visit us at home and the } \\
\text { risk of transmitting } \\
\text { COVID to my child }\end{array}$ & Ill11111 & Illlll & IIII & Il & 20 \\
\hline $\begin{array}{l}\text { h) I am worried about } \\
\text { nurses/carers coming to } \\
\text { visit us at home and the } \\
\text { risk of transmitting } \\
\text { COVID to me or my family } \\
\text { members }\end{array}$ & 111111111 & 11111 & 11111 & 11 & 21 \\
\hline i) any other: (please state) & & & & & \\
\hline
\end{tabular}

Mood and Behaviour - during the COVID-19 outbreak:

\begin{tabular}{|c|c|c|c|c|c|}
\hline $\begin{array}{l}\text { 4. Which of these feelings } \\
\text { or moods has your child } \\
\text { experienced during this } \\
\text { period }\end{array}$ & Never & Sometimes & Often & Always & \\
\hline a) happiness & & 1111111 & llllll & llllll & 19 \\
\hline b) irritability/moody & & 11111111111111111 & lll & & 20 \\
\hline
\end{tabular}




\begin{tabular}{|c|c|c|c|c|c|}
\hline c) angry & Illll & 1111111111111 & & & 19 \\
\hline d) sad/tearful & lllll & 11111111111 & Ill & & 19 \\
\hline e) depressed & 1111111111111 & llll & $\mathrm{l}$ & & 19 \\
\hline f) anxious/worried & llll & 11111111111 & lllll & & 20 \\
\hline g) panic attacks & 1111111111111111ll & ll & l & & 19 \\
\hline h) thoughts of self-harm & 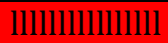 & ll & & & 18 \\
\hline $\begin{array}{l}\text { 5. Which of these } \\
\text { behaviours has your } \\
\text { child displayed during } \\
\text { this period }\end{array}$ & & & & & \\
\hline a) restless/fidgety & lll & 1111111111 & llllll & $\mathrm{l}$ & 20 \\
\hline b) lack of concentration & llll & 111111111 & llllll & ll & 20 \\
\hline $\begin{array}{l}\text { c) tired with low energy } \\
\text { levels }\end{array}$ & ll & 111111111111111ll & $\mathrm{l}$ & 1 & 20 \\
\hline d) relaxed & & 1111111111 & lllllllll & & 19 \\
\hline $\begin{array}{l}\text { e) participation in their } \\
\text { hobbies/activities }\end{array}$ & & 1ll11ll11ll1 & Illll & Ill & 19 \\
\hline $\begin{array}{l}\text { f) sleeping too little/worse } \\
\text { than before }\end{array}$ & 1111111 & lllll & Illll & Il & 19 \\
\hline g) sleeping too much & 111111111 & llllll & ll & ll & 19 \\
\hline h) loss of appetite & Illllllll & llllll & Illl & ll & 20 \\
\hline
\end{tabular}




\begin{tabular}{|l|l|l|l|l|l|}
\hline i) overeating & ll11ll1l & 111111111 & & 19 \\
\hline
\end{tabular}


Table 2:

COVID-19 SURVEY FOR CHILDREN AND ADOLESCENTS ATTENDING SPECIALIST ASTHMA SERVICE

Asthma Symptoms - during the COVID-19 outbreak:

\begin{tabular}{|c|c|c|c|c|c|}
\hline $\begin{array}{l}\text { 1. I have been worried } \\
\text { about: }\end{array}$ & Never & Sometimes & Often & Always & Total \\
\hline a) my asthma & 1111 & IIIIIII & 1 & 1 & 13 \\
\hline $\begin{array}{l}\text { b) my asthma symptoms } \\
\text { (cough/ wheeze/ } \\
\text { shortness of breath/tight } \\
\text { chest) }\end{array}$ & 1111 & 111111 & 111 & 1 & 14 \\
\hline $\begin{array}{l}\text { 2. Because of my } \\
\text { asthma, I am worried } \\
\text { about: }\end{array}$ & Never & Sometimes & Often & Always & Total \\
\hline $\begin{array}{l}\text { a) being able to see a } \\
\text { doctor if needed }\end{array}$ & 1111111 & 11111 & 1 & 1 & 14 \\
\hline $\begin{array}{l}\text { b) being able to speak to } \\
\text { my asthma team or } \\
\text { specialist service }\end{array}$ & 1111111 & 11111 & Il & & 14 \\
\hline $\begin{array}{l}\text { c) getting my asthma } \\
\text { medication prescriptions }\end{array}$ & 1111111111 & ll & & 11 & 14 \\
\hline $\begin{array}{l}\text { d) accessing the } \\
\text { pharmacy for my asthma } \\
\text { medications }\end{array}$ & 11111111 & 111 & & Ill & 14 \\
\hline e) going to the hospital & lll & IIIII & Ill & Ill & 14 \\
\hline $\begin{array}{l}\text { f) any other: (please } \\
\text { state) }\end{array}$ & & & & & \\
\hline $\begin{array}{l}\text { 3. My asthma has been } \\
\text { triggered by: }\end{array}$ & Never & Sometimes & Often & Always & Total \\
\hline $\begin{array}{l}\text { a) thinking about COVID- } \\
19\end{array}$ & 1111111111 & 111 & & 1 & 14 \\
\hline
\end{tabular}




\begin{tabular}{|c|c|c|c|c|c|}
\hline $\begin{array}{l}\text { b) worries about school } \\
\text { work }\end{array}$ & lll11ll & 111111 & 1 & & 14 \\
\hline $\begin{array}{l}\text { c) worries because of } \\
\text { information heard on } \\
\text { media outlets }\end{array}$ & Illllllll & 111 & 1 & 11 & 14 \\
\hline $\begin{array}{l}\text { d) worries because of } \\
\text { social distancing and not } \\
\text { being able to see my } \\
\text { friends/family }\end{array}$ & 1111111 & 11111 & 1 & 1 & 14 \\
\hline e) worries about money & 111111111111 & 11 & 1 & & 14 \\
\hline $\begin{array}{l}\text { f) worries from family } \\
\text { disagreements }\end{array}$ & llllllllllll & 1 & & 1 & 14 \\
\hline $\begin{array}{l}\text { g) worries about } \\
\text { nurses/carers coming to } \\
\text { visit me at home and the } \\
\text { risk of transmitting } \\
\text { COVID to me }\end{array}$ & 111111111 & Ill11 & l & & 14 \\
\hline $\begin{array}{l}\text { h) worries about } \\
\text { nurses/carers coming to } \\
\text { visit me at home and the } \\
\text { risk of transmitting } \\
\text { COVID to my family } \\
\text { members }\end{array}$ & 111111111 & 11111 & 1 & 1 & 14 \\
\hline i) any other: (please state) & & & & & \\
\hline
\end{tabular}

Mood and Behaviour - during the COVID-19 outbreak:

\begin{tabular}{|l|l|l|l|l|l|}
\hline $\begin{array}{l}\text { 4. Which of these feelings } \\
\text { or moods have you } \\
\text { experienced during this } \\
\text { period }\end{array}$ & Never & Sometimes & Often & Always & Total \\
\hline a) happiness & & lll & llll & llll & 12 \\
\hline b) irritability/moody & & ll111111 & ll & & 11 \\
\hline
\end{tabular}




\begin{tabular}{|c|c|c|c|c|c|}
\hline c) angry & lll & 11111111 & & & 11 \\
\hline d) sad/tearful & lll & lllllll & 1 & & 11 \\
\hline e) depressed & 111111111 & ll & & & 11 \\
\hline f) anxious/worried & lll & 1111111 & ll & & 12 \\
\hline g) panic attacks & llllllllll & l & & & 11 \\
\hline h) thoughts of self-harm & 1111111111 & l & & & 11 \\
\hline $\begin{array}{l}5 \text {. Which of these } \\
\text { behaviours have you } \\
\text { displayed during this } \\
\text { period }\end{array}$ & Never & Sometimes & Often & Always & Total \\
\hline a) restless/fidgety & 1111 & lll & 1111 & ll & 13 \\
\hline b) lack of concentration & lll & 11111 & lll & ll & 13 \\
\hline $\begin{array}{l}\text { c) tired with low energy } \\
\text { levels }\end{array}$ & lllll & 111111 & ll & & 13 \\
\hline d) relaxed & & 111111 & lllll & $\mathrm{l}$ & 12 \\
\hline $\begin{array}{l}\text { e) participation in your } \\
\text { hobbies/activities }\end{array}$ & & 111111 & llll & ll & 12 \\
\hline $\begin{array}{l}\text { f) I am sleeping too } \\
\text { little/worse than before }\end{array}$ & 11111 & 11111 & & ll & 12 \\
\hline g) I am sleeping too much & 11111111 & llll & l & & 13 \\
\hline h) I have lost my appetite & 11111 & llll & llll & & 13 \\
\hline
\end{tabular}




\begin{tabular}{|l|l|l|l|l|l|}
\hline i) I am eating too much & llll & lllll & l & & $\mathbf{1 2}$ \\
\hline
\end{tabular}

